\title{
PENINGKATAN KEMAMPUAN BERBICARA BAHASA INGGRIS SISWA MELALUI MODEL PEMBELAJARAN ROLE PLAY DI KELAS XII IPA 2 SMA N 1 SITIUNG TAHUN PELAJARAN 2015/2016
}

\author{
Tri Kartini \\ Guru SMA Negeri 1 Sitiung \\ Email: trikartinikotret@gmail.com
}

\begin{abstract}
The purpose of this research was to determine whether students speaking ability in English could be improved through the Roleplay Model. Class XII IPA 2 students of SMA Negeri I Sitiung Semester one in Academic Year 2015/2016 as research subjects and one English teacher as an observer. Researcher conducted pre-observations by interviewing several students and observing the conditions before conducting the study. From the results of pre-observations, it was found that the students' speaking ability was not good, so research was needed. This study consisted of two cycles. In the first cycle, the researcher found that $40 \%$ of students who were able to speak English. Whereas in the second cycle $84 \%$ of students were able to speak English. From this result, it can be concluded that through Role Play can improve students' speaking ability.

Keywords: speaking ability, English, role play model learning
\end{abstract}

\begin{abstract}
Abstrak
Tujuan dari penelitian ini adalah untuk mengetahui apakah kemampuan berbicara dalam bahasa Inggris siswa dapat ditingkatkan melalui Model Roleplay. Siswa kelas XII IPA 2 SMA Negeri I Sitiung Semester I Tahun Ajaran 2015/2016 sebagai subjek penelitian dan seorang guru Bahasa Inggris sebagai pengamat. Peneliti melakukan observasi awal dengan mewawancarai beberapa siswa dan mengamati kondisi sebelum melakukan penelitian. Dari hasil observasi pendahuluan diketahui bahwa kemampuan berbicara siswa kurang baik sehingga diperlukan penelitian. Penelitian ini terdiri dari dua siklus. Pada siklus pertama, peneliti menemukan bahwa 40\% siswa mampu berbahasa Inggris. Sedangkan pada siklus II $84 \%$ siswa sudah mampu berbahasa Inggris. Dari hasil ini dapat disimpulkan bahwa melalui Role Play dapat meningkatkan kemampuan berbicara siswa.

Kata kunci: kemampuan berbicara, bahasa Inggris, model pembelajaran role play
\end{abstract}

\section{PENDAHULUAN}

Kemampuan berbicara Bahasa Inggris siswa masih merupakan permasalah dalam pembelajaran di pendidikan tingkat menengah. Begitu juga di kelas XII IPA 2 SMAN Sitiung. Penulis masih menemukan siswa yang tidak termotivasi untuk berbicara bahasa inggris.. Dan kemampuan berbicara siswa SMA Negeri 1 
Sitiung kelas XII IPA 2 Tahun Pelajaran 2015/2016 masih sangat kurang, karena ada beberapa faktor, baik dari guru, lingkungan dan dari siswa itu sendiri.

Peneliti menemukan permasalah pembelajaran dimana guru hanya berfokus pada buku pelajaran atau buku paket yang ada. Sehingga pembelajaran terkesan monoton, kurang menarik bagi siswa dan tidak memotivasi siswa untuk memulai berbicara bahasa Inggris. Siswa kebingungan untuk memulai berbicara dalam bahasa inggris. Sehingga ketika siswa diminta untuk berbicara dalam bahasa Inggris mereka ketakutan dan malu. Ketika siswa diajak untuk berkomunikasi dengan bahasa Inggris, mereka kesulitan untuk menyampaikan idenya, karena mereka takut kata - kata yang mereka ucapkan akan salah dan jadi bahan tertawaan bagi teman - temannya.

Berdasarkan data pra observasi yang dilakukan peneliti dari ke dua kelas XII program studi IPA (XII IPA 1dan XII IPA 2) berjumlah siswa 53 orang; XII IPA 1 berjumlah 28 orang dan XII IPA 2 berjumlah 25 orang, diperoleh data bahwa tingkat kemampuan berbicara bahasa inggris siswa kelas XII IPA 2 masih sangat rendah.

\section{Kemampuan Berbicara Bahasa Inggris}

Kemampuan berbicara adalah kemampuan untuk mengungkapkan pendapat atau pikiran dan perasaan kepada seseorang atau kelompok secara lisan, baik secara berhadapan ataupun dengan jarak jauh. Selain itu berbicara merupakan alat untuk mengungkapkan pikiran dan sebagai bentuk tingkah laku sosial. Jadi kemampuan berbicara adalah kemampuan menyusun kalimat-kalimat untuk menampilkan perbedaan tingkah laku yang bervariasi dari masyarakat yang berbeda. Jadi, berbicara adalah sebuah kegiatan yang dilakukan seseorang kepada orang lain tentang suatu hal atau kegiatan percakapan yang dilakukan seseorang kepada orang lain. Dalam berkomunikasi atau berbicara diperlukan sebuah alat yang disebut bahasa. Hornby (2005) mendefinisikan bahasa itu sendiri sebagai berikut;

"Language is a human and non instinctive method of communicating ideas, feeling, and desires by means of a system of sound and sound symbols".

\section{Pengertian Role Play Model}

Pembelajaran dengan role playing adalah suatu cara penguasaan bahanbahan pelajaran melalui pengembangan imajinasi dan penghayatan siswa. Pengembangan imajinasi dan penghayatan itu dilakukan siswa dengan memerankannya sebagai tokoh hidup atau benda mati. Metode ini banyak melibatkan siswa dan membuat siswa senang belajar serta metode ini mempunyai nilai tambah, yaitu: a) dapat menjamin poartisipasi seluruh siswa dan memberi kesempatan yang sama untuk menunjukkan kemampuannya dalam bekerjasama hingga berhasil, dan b) permainan merupakan pengalaman yang menyenangkan bagi siswa (Prasetyo, 2001).

Pembelajaran dengan role playing merupakan suatu aktivitas yang perantik,biasanya ditampilkan oleh sekelompok kecil siswa, bertujuan mrngeksploitasi beberapa masalah yang ditemukan untuk melengkapi partisipasi dan pengamat dengan pengalaman belajar yang nantinya dapat meningkatkan pemahaman (Prasetyo, 2001). 


\section{METODOLOGI PENELITIAN \\ Lokasi dan Waktu Penelitian}

Penelitian ini dilaksanakan pada bulan Februari sampai bulan Juni tahun 2015 dikelas XII IPA 2 semester satu tahun Pelajaran 2015/2016 di SMA Negeri 1 Sitiung, Kabupaten Dharmasraya. Siklus 1 dilaksanakan 2 kali pertemuan. Pertemuan 1 pada tanggal 16 September 2015 dan pertemuan 2 pada tanggal 30 September 2015. Siklus 2 dilaksanakan 2 kali pertemuan. Pertemuan 1 pada tanggal 7 Oktober 2015 dan pertemuan 2 pada tanggal 4 November 2015. Subjek penelitian ini adalah seluruh siswa kelas XII IPA 2 SMAN I Sitiung Tahun Pelajaran 2015/2016 yang berjumlah 25 orang yang terdiri dari laki - laki sebanyak 9 orang dan perempuan sebanyak 16 orang. Mereka memiliki kemampuan rata - rata. Guru sebagai peneliti terlibat langsung dalam planning, acting, observing, dan reflecting tindakan-tindakan yang dibantu oleh guru bahasa inggris lainnya sebagai kolaborator.

\section{Prosedur Penelitian}

Pelaksanaan penelitian ini dilakukan dalam dua siklus, melalui tahapan langkah - langkah yaitu perencanaan, pelaksanaan, pengamatan, dan refleksi.

\section{Perencanaan}

Peneliti merancang tindakan berdasarkan tujuan penelitian sebagaimana telah dijabarkan di atas. Beberapa instrumen yang disiapkan yaitu rencana pembelajaran (RPP), buku bahan ajar, percakapan yang menarik dan sederhana, lembar observasi nilai sikap, lembar penilaian kemampuan berbicara dan kamera foto. Semua instrumen tersebut divalidasi oleh rekan sejawat dan telah diizinkan serta disetujui oleh Kepala Sekolah. Adapun rencana langkah - langkah tindakan dalam penelitian ini adalah sebagai berikut ini;

1) Guru akan memotivasi, apersepsi dan memyanpaikan tujuan pembelajaran

2) Siswa akan dibagi dalam kelompok kecil

3) Guru menyampaikan model pembelajaran role play

4) Guru mendiskusikan pemahaman tentang beberapa percakapan

5) Guru memberikan kesempatan kepada siswa secara kelompok untuk bertanya tentang hal yang belum jelas

6) Siswa berdiskusi untuk menentukan pemeran dalam role play

7) Guru memamtau siswa yang berdiskusi dalam kelompok dan memberikan bantuan dan penguatan jika siswa menemukan kendala

8) Kelompok secara bergiliran berlatih menampilkan role play di depan kelas, dan guru memberikan perbaikan

9) Kelompok menampilkan role play untuk dilaksanakan penilaiannya

10) Guru akan mengamati kemampuan berbicara bahasa inggris siswa.

\section{Pelaksanaan}

Semua kegiatan yang direncanakan dapat dilaksanakan dalam pembelajaran. Guru selaku peneliti langsung melaksanakan tindakan sesuai dengan apa yang sudah direncanakan dalam tahap perencanaan penelitian. Peneliti dalam melaksanakan tindakan penelitian menggunakan model role play sebagai bentuk perbaikan pembelajaran.

Kegiatan inti mencakup penjelasan tentang kegiatan yang akan dilaksanakan untuk memainkan peran cerita dalam percakapan dengan model role play; pemantauan kegiatan kelompok; penampilan role play masing - masing kelompok dievaluasi oleh guru; diskusi kesulitan dan solusinya; dan penegasan 
pengucapan yang benar dari percakapan yang telah mereka buat. Sedangkan Kegiatan penutup meliputi pemberian apresiasi pada semua siswa, pemberian tugas mandiri, dan do'a penutup.

\section{Pengamatan}

Pengamatan dilakukan oleh peneliti itu sendiri dan dibantu oleh observer atau kolaborator yaitu Zulkhairi, S.Pd.Ing dengan mengisi instrumen yang telah disediakan. Dalam tahap pengamatan, observer akan menggunakan instrumen yaitu berupa lembar observasi penilaian sikap dan lembar penilaian kemampuan berbicara siswa untuk memotret proses pembelajaran yang menggunakan role play. Observer mengamati dengan seksama pelaksanaan pembelajaran dan mengisi lembar observasi selama proses penelitian. Observer mengamati dan mengisi lembar observasi dengan jujur dan objektif tanpa adanya intervensi dari peneliti.

Refleksi

Isian lembar instrumen pengamatan (lembar observasi) dan lembar penilaian kemampuan berbicara siswa dalam kegiatan pembelajaran dikaji secara teliti. Masukan-masukan serta kritikan-kritikan yang membangun dari guru observer ditindaklanjuti untuk perbaikan dan peningkatan kegiatan pembelajaran pada siklus berikutnya. Wawancara secara informal pada beberapa siswa saat jam istirahat juga menjadi masukan yang sangat berarti untuk peningkatan kegiatan pembelajaran selanjutnya.

\section{HASIL PENELITIAN DAN PEMBAHASAN \\ Deskripsi Kondisi Awal}

Pada awal semester satu tahun pelajaran 2015/2016, siswa kembali malas dan malu untuk memulai dan merespon percakapan bahasa inggris. Padahal pada semester sebelumnya kemampuan berbicara siswa sudah maksimal. Dari 25 siswa terdapat 9 siswa yang mau merespon langsung percakapan guru dengan menggunakan bahasa inggris sedangkan siswa lainnya yang perlu mendapat bimbingan/bantuan secara individual dalam pembelajaran bahasa inggris.

Hasil pelaksanaan pra observasi menunjukkan terdapat sepuluh orang siswa yang aktif dalam proses pembelajaran bahasa Inggris di kelas XII IPA 2 pada semester satu tahun pelajaran 2015/2016. Sedangkan 60\% siswa tidak mencapai nilai batas minimal dalam penilaian berbicara bahasa inggris.

\section{Pelaksanaan Siklus Pertama \\ Perencanaan}

1) Dalam perencanaan guru memotivasi, apersepsi dan menyampaikan tujuan pembelajaran

2) Siswa dibagi dalam kelompok kecil yang erdiri tiga atau empat orang.

3) Guru menyampaikan strategi pembelajaran dengan menerapkan role play

4) Guru memberikan kesempatan kepada siswa secara kelompok untuk bertanya tentang hal yang belum jelas

5) Guru dan siswa membahas teks percakapan

6) Guru memberikan kebebasan pada masing - asing kelompok untuk memilih text percakapanyang akan ditampilkan.

7) Guru membuat catatan pribadi

8) Guru mengamati aktivitas dan kemampuan siswa. 
9) Guru menilai kemampuan berbicara siswa dalam bermain peran dengan menggunakan rubric penilaian

\section{Pelaksanaan}

Pelaksanaan pada siklus pertama penelitian tindakan kelas, guru melakukan beberapa tindakan yaitu :

1) Guru memotivasi, apersepsi dan menyampaikan tujuan pembelajaran. Menjelaskan rencana kegiatan saat itu, yaitu mendiskusikan Setelah itu siswa diminta untuk duduk berkelompok.

2) Guru menyampaikan penilaian kemampuan berbicara siswa, yaitu seperti yang terlampir di rubric penilaian.

3) Guru memberikan kesempatan kepada siswa secara kelompok untuk bertanya tentang hal yang belum jelas

4) Guru memberikan kebebasan kelompok berekspresi role play yang mereka sukai. Guru membuat catatan pribadi

5) Guru dan kolaborator mengamati aktivitas siswa. Guru menilai kemampuan berbicara siswa dalam bermain peran dengan menggunakan rubric penilaian

\section{Hasil}

\section{Pertemuan pertama}

Siklus pertama dilaksanakan dalam dua kali pertemuan, dan dari lembar penilaian kemampuan berbicara siswa peneliti dapat mengemukakan bahwa pada siklus pertama pertemuan pertama didapatkan data sebagai berikut: dari jumlah siswa, sepuluh siswa yang mampu berkomunikasi dengan bahasa inggris sesuai dengan kriteria penilaian. Dan lima belas siswa lainnya masih ragu - ragu untuk menggunakan bahasa inggris. Jadi siswa yang mampu berbicara bahasa inggris melalui role play pada pertemuan pertama adalah $40 \%$. Prasentase kemampuan berbicara bahasa inggris siswa pada siklus pertama pertemuan pertama dapat dilihat pada Tabel 1. berikut:

Tabel 1. Rentang penilaian kemampuan berbicara siswa dan kategori nilai dan persentase

\begin{tabular}{|c|c|c|c|c|}
\hline No & $\begin{array}{c}\text { Rentang penilaian } \\
\text { kemampuan berbicara }\end{array}$ & Kategori & $\begin{array}{c}\text { Jumlah } \\
\text { siswa }\end{array}$ & $\%$ \\
\hline 1 & $95-100$ & Excellent & 4 & 16 \\
\hline 2 & $85-94$ & Very good & 3 & 12 \\
\hline 3 & $78-84$ & Good & 3 & 12 \\
\hline 4 & $70-77$ & Satisfactory & 5 & 20 \\
\hline 5 & $\leq 69$ & Poor & 10 & 40 \\
\hline & & & 25 & 100 \\
\hline
\end{tabular}

Pada tabel di atas menunjukkan bahwa kemampuan berbicara siswa dalam belajar Bahasa inggris belum mengalami peningkatan signifikan pada pertemuan pertama. Siswa yang memperoleh rentang nilai 95-100 (excellent) sebanyak empat orang. Siswa yang memperoleh rentang nilai 85-94 (very good) berjumlah tiga orang siswa. Sedangkan pada level rentang nilai $78-84$ (good) tiga orang. Dan pada rentang nilai 70-77 (satisfactory) berjumlah lima orang . Selanjutnya pada rentang $\leq 69$ atau level poor sebanyak sepuluh siswa. 


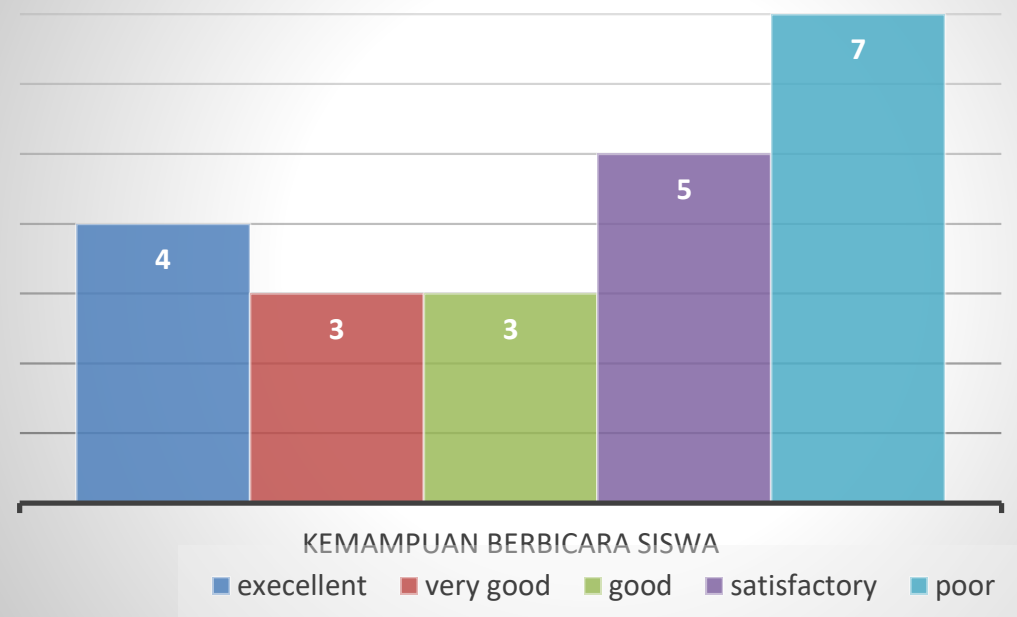

Grafik 1. Kemampuan berbicara siswa pada siklus satu pertemuan pertama

\section{Pertemuan kedua}

Siklus pertama pada pertemuan kedua penilaian kemampuan berbicara siswa peneliti dapat mengemukakan bahwa pada siklus pertama pertemuan kedua didapatkan data sebagai berikut: dari jumlah siswa, enam siswa yang mampu berkomunikasi dengan bahasa inggris dengan kriteria penilaian excellent, lima orang siswa dengan penilaian very good, lima orang siswa pada level good, lima siswa pada level satisfactory dan empat orang pada level poor. Dengan demikian jumlah siswa yang memperoleh nilai diatas 78 adalah enam belas orang, atau $64 \%$. Persentase kemampuan berbicara bahasa inggris siswa pada siklus pertama pertemuan kedua dapat dilihat pada Tabel 2. berikut:

Tabel 2. Hasil kemampuan berbicara, kategori, jumlah siswa dan persentase siswa pada siklus pertama pertemuan kedua

\begin{tabular}{|c|c|c|c|c|}
\hline No. & $\begin{array}{c}\text { Rentang penilaian } \\
\text { kemampuan berbicara }\end{array}$ & Kategori & $\begin{array}{c}\text { Jumlah } \\
\text { siswa }\end{array}$ & $\%$ \\
\hline 1. & $95-100$ & Excellent & 6 & 24 \\
\hline 2. & $85-94$ & Very good & 5 & 20 \\
\hline 3. & $78-84$ & Good & 5 & 20 \\
\hline 4. & $70-77$ & Satisfactory & 5 & 20 \\
\hline 5. & $\leq 69$ & Poor & 4 & 16 \\
\hline & Jumlah Siswa & & 25 & 100 \\
\hline
\end{tabular}

Pada tabel 2 di atas menunjukkan bahwa kemampuan berbicara siswa dalam belajar Bahasa inggris mengalami peningkatan signifikan pada pertemuan kedua. 


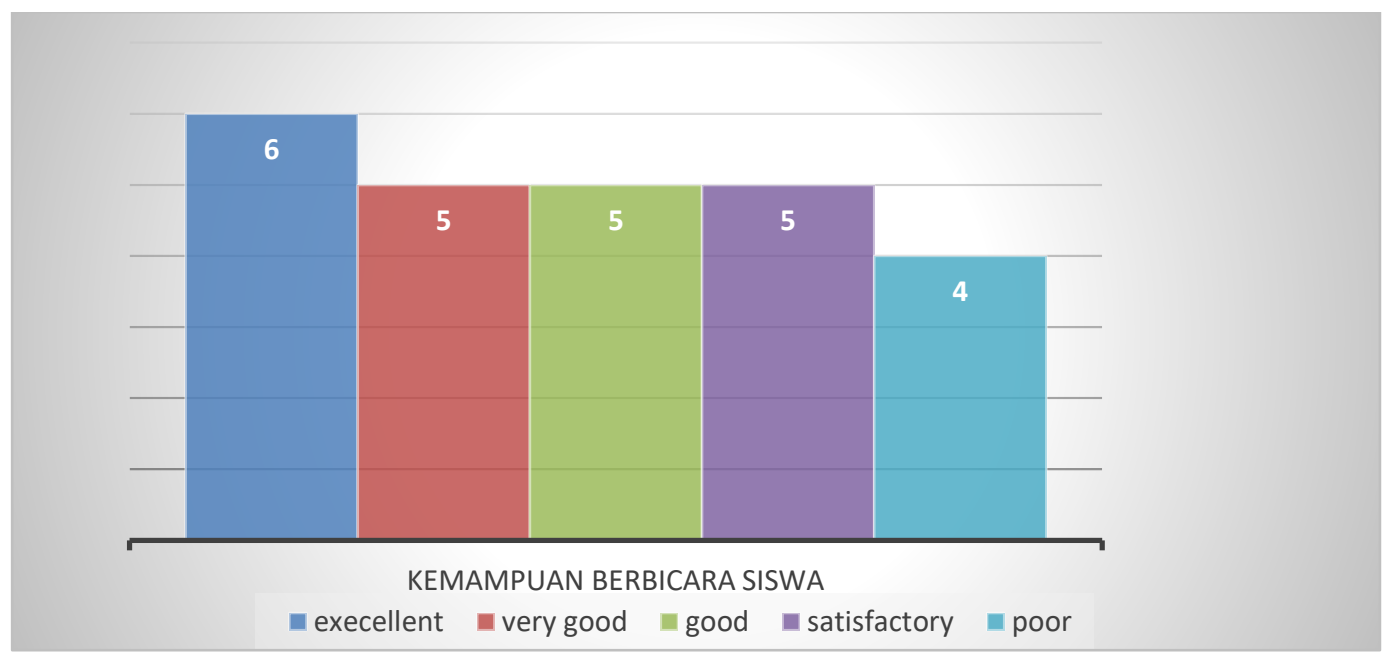

Gambar 2. Kemampuan belajar siswa pada siklus satu pertemuan kedua

\section{b. Refleksi}

Dari siklus pertama, setelah dilakukan analisa, terhadap hasil kemampuan berbicara siswa, catatan harian dan wawancara singkat terhadap siswa dan diskusi dengan kolaborator maka diperoleh hasil berikut: siswa tidak mampu mengungkapkan kalimat atau percakapan dengan tepat dan mereka lupa dengan kosa kata, merasa minder dengan siswa yang dikelompok lain.

Dengan demikian peneliti berdiskusi dengan kolaborator dan menentukan tindakan selanjutnya yaitu memotivasi siswa untuk berbicara atau mengomunikasi dalam bahasa inggris. Jadi peneliti sebelum melanjutkan ke siklus kedua, peneliti menyampaikan kepada seluruh siswa untuk mempersiapkan satu game bahasa inggris pada pertemuan berikutnya.

\section{Siklus Kedua}

\section{Perencanaan}

1) Guru memotivasi, apersepsi dan menyampaikan tujuan pembelajaran Menjelaskan rencana kegiatan saat itu, yaitu mendiskusikan Setelah itu siswa diminta untuk duduk berkelompok.

2) Guru menyampaikan penilaian kemampuan berbicara siswa, yaitu seperti yang terlampir di rubric penilaian.

3) Guru memberikan kesempatan kepada siswa secara kelompok untuk bertanya tentang hal yang belum jelas

4) Guru memberikan kebebasan kelompok berekspresi role play yang mereka sukai.

5) Guru membuat catatan pribadi. Guru dan kolaborator mengamati aktivitas siswa.

6) Guru menilai kemampuan berbicara siswa dalam bermain peran dengan menggunakan rubric penilaian

\section{Pelaksanaan}

Pelaksanaan pada siklus kedua penelitian tindakan kelas, guru melakukan beberapa tindakan dalam perencanaan sesuai dalam rencana pelaksanaan pembelajaran. 


\section{Hasil}

1. Pertemuan pertama

Siklus pertama dilaksanakan dalam dua kali pertemuan, dan dari lembar penilaian kemampuan berbicara siswa peneliti dapat mengemukakan bahwa pada siklus kedua pertemuan pertama didapatkan data sebagai berikut: dari jumlah siswa, enam belas siswa yang mampu berkomunikasi dengan bahasa inggris sesuai dengan kriteria penilaian .

Prasentase kemampuan berbicara bahasa inggris siswa pada siklus kedua pertemuan pertama dapat dilihat pada Tabel 3. berikut:

Tabel 3. Hasil kemampuan berbicara, kategori, jumlah siswa dan persentase siswa pada siklus kedua pertemuan petama

\begin{tabular}{|c|c|c|c|c|}
\hline No & $\begin{array}{c}\text { Rentang penilaian } \\
\text { kemampuan berbicara }\end{array}$ & Kategori & $\begin{array}{c}\text { Jumlah } \\
\text { siswa }\end{array}$ & $\%$ \\
\hline 1 & $95-100$ & Excellent & 6 & 24 \\
\hline 2 & $85-94$ & Very good & 5 & 20 \\
\hline 3 & $78-84$ & Good & 6 & 24 \\
\hline 4 & $70-77$ & Satisfactory & 4 & 16 \\
\hline 5 & $\leq 69$ & Poor & 4 & 16 \\
\hline & Jumlah Siswa & & 25 & 100 \\
\hline
\end{tabular}

Pada tabel 3 di atas menunjukkan bahwa kemampuan berbicara siswa dalam belajar Bahasa inggris tidak mengalami peningkatan pada pertemuan pertama. Jumloah siswa yang mampu memainkan peran dan berbicara bahasa inggris sesuai dengan criteria penilaian hampir sama dengan hasil pada siklus pertama.

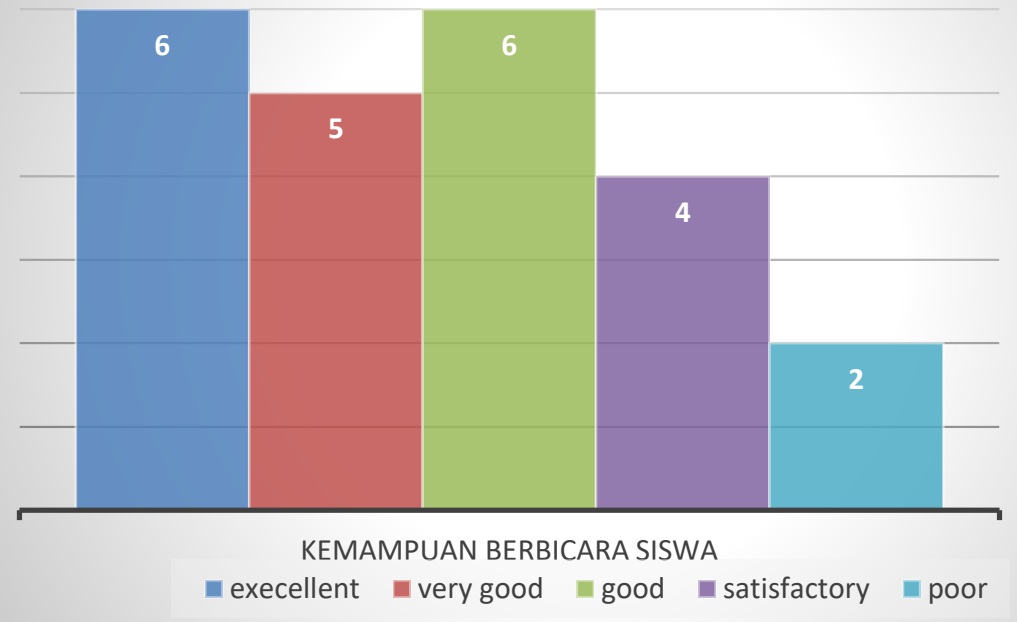

Gambar 3. Kemampuan belajar siswa pada siklus kedua pertemuan pertama

\section{Pertemuan kedua}

Siklus kedua pada pertemuan kedua penilaian kemampuan berbicara siswa peneliti dapat mengemukakan bahwa pada siklus kedua pertemuan kedua didapatkan data sebagai berikut: dari jumlah siswa, tujuh siswa yang mampu berkomunikasi dengan bahasa inggris dengan kriteria penilaian excellent, enam orang siswa dengan penilaian very good, delapan orang siswa pada level good, 
tiga siswa pada level satisfactory dan satu siswa pada level poor. Dengan demikian jumlah siswa yang memperoleh nilai diatas 78 adalah dua puluh satu orang. Persentase kemampuan berbicara bahasa inggris siswa pada siklus pertama pertemuan kedua dapat dilihat pada Tabel 4. berikut:

\begin{tabular}{|c|c|c|c|c|}
\hline No & $\begin{array}{c}\text { Rentang penilaian } \\
\text { kemampuan berbicara }\end{array}$ & Kategori & $\begin{array}{c}\text { Jumlah } \\
\text { siswa }\end{array}$ & $\%$ \\
\hline 1 & $95-100$ & Excellent & 7 & 28 \\
\hline 2 & $85-94$ & Very good & 6 & 24 \\
\hline 3 & $78-84$ & Good & 8 & 32 \\
\hline 4 & $70-77$ & Satisfactory & 3 & 12 \\
\hline 5 & $\leq 69$ & Poor & 1 & 4 \\
\hline & & & 25 & 100 \\
\hline
\end{tabular}

Pada tabel 4 di atas menunjukkan bahwa kemampuan berbicara siswa dalam belajar Bahasa inggris mengalami peningkatan signifikan pada pertemuan kedua.

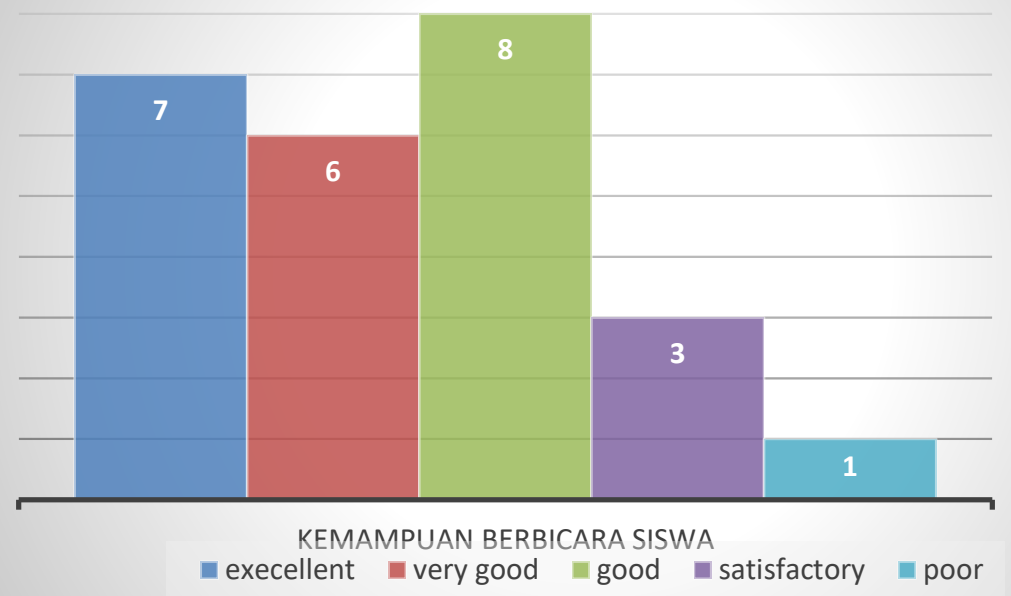

Gambar 4. Kemampuan belajar siswa pada siklus kedua pertemuan kedua

\section{a. Refleksi}

Dari siklus kedua, setelah dilakukan analisa, terhadap hasil kemampuan berbicara siswa, catatan harian dan wawancara singkat terhadap siswa dan diskusi dengan kolaborator maka diperoleh hasil berikut: siswa mampu berkomunikasi dengan bahasa inggris melalui role play berjumlah dua puluh satu siswa.Dengan demikian peneliti mengakhiri penelitian tindakan kelas ini.

\section{PEMBAHASAN}

Pada siklus pertama menunjukkan bahwa ada peningkatan kemampuan berbicara bahasa inggris siswa. Akan tetapi pada siklus pertama ada sepuluh siswa yang mencapai lebih dari 78. Pada pertemuan kedua di siklus pertama terjadi peningkatan kemampuan berbicara siswa menjadi enam belas siswa. Siklus kedua dilaksanakan dalam dua kali pertemuan, dan dari lembar penelitian 
peneliti dapat mengemukakan bahwa pada akhir siklus kedua didapatkan data bahwa ada dua puluh satu siswa yang telah mencapai nilai lebih dari 78 .

\section{KESIMPULAN}

Berdasarkan hasil penelitian peningkatan aktivitas belajar bahasa Inggris siswa kelas XII IPA 2 maka dapat disimpulkan bahwa melalui penerapan role play dalam pembelajaran bahasa inggris menunjukkan adanya peningkatan dalam kemampuan berbicara siswa di kelas XII IPA 2 Semester 1 Tahun Pelajaran 2015/2016.

\section{Saran}

Berdasarkan pengalaman dalam penelitian tindakan kelas ini maka disarankan guru untuk mempersiapkan strategi yang menarik, merancang scenario pembelajaran yang menciptakan kelas lebih interaktif dan komunikatif dan memilih teks yang familiar dengan siswa. Guru dalam mengajar sebaiknya tidak hanya berfokus pada buku paket. Guru sebaiknya bersikap ramah, komunikatif, dan siap membantu siswa yang mengalami kesulitan. Ciptakanlah learning community, karena hal ini sangat membantu siswa dalam belajar dan melaksanakan authentic assessment pada setiap pembelajaran.

\section{DAFTAR PUSTAKA}

Anderson, Mark. 1997. Text Type in English 2. Australia: Mackmillan

Chamot, Anna Uhl, dkk. (1999). The Learning Strategies Handbook. New York: Longman, Inc

Hamalik, O. (2004). Proses Belajar Mengajar. Jakarta: Bumi Aksara.

Hornby (2015). Testing English as a Second Language. New York: Mc Grow-hill.

Hughes, Arthur. (2002). Testing For Language Teacher. Cambridge: Cambridge University Press.

Kemmis, Stephen dan Robin McTaggart. (1988). The Action Research Planner. Victoris: Daikin University.

Mulyasa. 2005. Role Play for Teaching Speaking. Jakarta: Kalam Mulia

Prasetyo. 2011. Role )Play sebagai Strategi pembelajaran. Jakarta : Rineka Cipta Silberman, M. 2002. Active Learning 101 Model Pembelajaran. Yogyakarta: Yappendis.

Weir, C J. 1993. Understanding and Developing Language Tests. Trowbridge: prentice Hall International. 